\title{
UPAYA MEWUJUDKAN GERAKAN INDONESIA BERSATU SEBAGAI BENTUK GERAKAN REVOLUSI MENTAL DALAM PROSES PEMBELAJARAN
}

\author{
Diorima Simatupang ${ }^{\bowtie}$, Noviyanti Yuliana, Siti Khoerunnisa, Syelpia Kotrunida M, \\ Firdian Setiya Arinata
}

Universitas Negeri Semarang

\begin{abstract}
Info Artikel Abstrak
Sejarah Artikel:

Disubmit: September

2021

Direvisi: Oktober 2021

Diterima: November

2021

Keywords:

United Indonesia

Movement; Tolerance;

Social Studies Learning

Keberagaman latar belakang masyarakat Indonesia dan permasalahan yang sering muncul akibat keberagaman tersebut membuat pemerintah Indonesia sangat serius dalam menciptakan masyarakat Indonesia yang mampu menerima dan menghargai keberagaman tersebut serta meningkatkan karakter toleransi antar masyarakat Indonesia. Pelaksanaan Gerakan Indonesia Bersatu juga menjadi tanggung jawab seluruh lapisan masyarakat Indonesia khususnya lembaga pendidikan. Pendidikan IPS merupakan salah satu upaya yang dapat memfasilitasi terselenggaranya Gerakan Indonesia Bersatu dan mewujudkan masyarakat yang toleran. Materi mengenai toleransi yang terkandung dalam pelajaran IPS merupakan salah satu bentuk nyata yang dapat diimplementasikan oleh lembaga pendidikan untuk melaksanakan dan melaksanakan Gerakan Indonesia Bersatu dalam lingkup pendidikan.
\end{abstract}

\begin{abstract}
The diversity of Indonesian people's backgrounds and the problems that often arise due to this diversity make the Indonesian government very serious in creating Indonesian people who are able to accept and respect this diversity and increase the character of tolerance among Indonesian people. The implementation of the United Indonesia Movement is also the responsibility of all levels of Indonesian society, especially educational institutions. Social studies education is one of the efforts or forums that can facilitate the implementation of the United Indonesia Movement and create a tolerant society. . The plurality of materials contained in the content of social studies subject matter is one of the tangible forms used by educational institutions to implement the United Indonesia Movement in the scope of education.
\end{abstract}

\footnotetext{
Alamat korespondensi:

Universitas Negeri Semarang

Kampus Sekaran, Gunungpati, Semarang, 50229

E-mail: diosimatupang@gmail.com
}

ISSN 2252-7133

E-ISSN 2548-4648 


\section{PENDAHULUAN}

Bangsa Indonesia mempunyai ciri khas sebagai masyarakat majemuk dan pluralistik. Berbicara mengenai masyarakat majemuk maka akan sangat erat kaitannya dengan kehidupan masyarakat yang mencerminkan rasa toleransi ditengah perpaduan suku, agama, serta adat istiadat yang berbeda. Sikap atau rasa toleransi menjadi salah satu indikator yang sangat penting dalam mewujudkan konsep masyarakat pluralistik, seperti yang kita ketahui keberagaman dan kemajemukan yang dimiliki Indonesia merupakan potensi yang dapat kita banggakan, namun dilain sisi keberagaman dan kemajemukan yang ada pada bangsa kita ini seringkali menimbulkan berbagai gesekan yang mampu menciptakan sebuah konflik.

Konflik yang terjadi di kota Ambon pada tahun 1999, Konflik Poso, dan Konflik antaretnis di kota Sampit menjadi bukti nyata bahwa diperlukan berbagai upaya untuk mewujudkan masyarakat pluralistic yang mampu memahami dan mengimplementasikan konsep masyarakat majemuk dan rasa toleransi satu sama lain. Toleransi menjadi salah satu topik menarik yang selalu dibicarakan oleh berbagai lapisan masyarakat, khususnya pemerintah guna mewujudkan masyarakat Indonesia yang sesuai dengan semboyan bangsa Indonesia yakni Bhinneka Tunggal Ika. Berbagai upaya terus dilakukan oleh pemerintah, salah satunya melalui terobosan "Gerakan Nasional Revolusi Mental" yang diatur dalam Instruksi Presiden (Inpres) 12 tahun 2016.

Menurut Instruksi Presiden (Inpres) 12 Tahun 2016 menjelaskan bahwa Gerakan Nasional Revolusi Mental merupakan program pemerintah yang bertujuan untuk memperbaiki dan membangun karakter bangsa Indonesia serta membangun budaya bangsa yang bermartabat, modern, maju, makmur, dan sejahtera berdasarkan Pancasila. Gerakan Nasional Revolusi Mental mencakup lima bentuk gerakan yakni Gerakan Indonesia Melayani, Gerakan Indonesia Bersih, Gerakan Indonesia Tertib, Gerakan Indonesia Mandiri, dan Gerakan Indonesia Bersatu. Berdasarkan Instruksi Presiden (Inpres) 12 Tahun 2016 Nomor 5 point b menjelaskan bahwa Gerakan Indonesia Bersatu difokuskan kepada peningkatan perilaku toleran dan kerukunan inter dan antar umat beragama. Melalui Inpres 12 Tahun 2016 Nomor 5 point $b$ menunjukkan bahwa pemerintah terus berusaha menciptakan berbagai upaya berkelanjutan guna mewujudkan masyarakat majemuk yang toleran satu sama lain.

Sebelum membahas lebih jauh mengenai Gerakan Indonesia Bersatu sebagai upaya pemerintah dalam mewujudkan masyarakat plural yang toleran, perlu diketahui konsep "Toleransi" itu sendiri. Toleransi berasal dari bahasa Latin yakni "tolerare" yang memiliki arti sabar terhadap sesuatu, mengutip pernyataan Abu Bakar bahwa Toleransi merupakan suatu sikap atau perilaku manusia yang mengikuti aturan, dimana seseorang dapat menghargai, menghormati terhadap perilaku orang lain (Bakar, 2015). Randa menjelaskan bahwa toleransi merupakan sikap saling menghormati, menghargai, dan menerima perbedaan, selain itu Randa juga menyampaikan juga fungsi tolernasi yakni untuk memahami perbedaan (SODIK, 2020).

Melalui pernyataan para ahli tersebut maka dapat disimpulkan bahwa toleransi merupakan suatu sikap indivindu yang mampu menghormati, menghargai dan menerima perbedaan atau dalam arti lain "toleransi" merupakan suatu sikap seorang indivindu maupun kelompok dalam menolak diskriminasi terhadap kemajemukan yang ada. Menurut Sodik memiliki rasa toleransi dan mengimplementasikan sikap tersebut dalam kehidupan sosial memiliki berbagai manfaat diantarannya mampu menciptakan kerukunan dan keharmonisa, memperkuat hubungan antar indivindu, meningkatkan rasa kebersamaan dan solidaritas serta mampu menciptakan lingkungan masyarakat yang nyaman dan tentram (SODIK, 2020).

Gerakan Indonesia bersatu menjadi salah satu upaya yang diharapkan pemerintah melalui Gerakan Nasional Revolusi Mental mampu menciptakan masyarakat Indonesia yang toleran dan diharapkan melalui implementasi Gerakan Indonesia Bersatu, masyarakat Indonesia 
mampu merasakan dampak dan manfaat sikap toleransi itu sendiri. Menurut artikel yang ditulis oleh Nawir \& Zultan menjelaskan bahwa Gerakan Indonesia Bersatu merupakan salah satu upaya dalam menjaga keberagaman sebagai suatu modal kekayaan budaya bangsa dan kekuatan nasional, selain itu Nawir \& Zultan menjelaskan bahwa melalui gerakan ini diharapkan pemerintah dan seluruh lapisan masyarakat dapat bekerjasama dan bergotongroyong dalam menciptakan masyarakat majemuk yang toleran (Nawir \& Zultan, 2018). Gerakan Indonesia Bersatu merupakan suatu upaya serta tanggung jawab seluruh lapisan masyarakat Indonesia, tidak hanya menjadi tugas pemerintah Indonesia, dalam hal ini lembaga pendidikan juga memiliki tanggung jawab tidak hanya mengimplementasikan Gerakan Indonesia Bersatu dalam proses pembelajaran melainkan juga mampu menciptakan generasi penerus bangsa yang memahami serta mampu mengimplementasikan sikap toleransi dalam kehidupan sosial.

Perlu diketahui sikap toleransi merupakan salah satu nilai karakter dalam dunia pendidikan. Menurut Kementerian Pendidikan Nasional (2011) terdapat 18 nilai karakter dan salah satu diantaranya yakni toleransi, nilai karakter toleransi merupakan salah satu nilai karakter yang bersumber pada ajaran agama, Pancasila dan tujuan pendidikan itu sendiri (Samani \& Hariyanto, 2020). Dalam hal ini menunjukkan bahwa toleransi merupakan salah satu nilai yang harus dikembangkan dan lembaga pendidikan yakni pendidik dan sekolah memiliki tanggung jawab dalam mengembangkan dan menanamkan nilai toleransi kepada peserta didik sebagai calon penerus bangsa dan bagian dalam kehidupan sosial masyarakat. Suciartini menyatakan bahwa sekolah, guru dan pendidikan merupakan bagian yang saling terintergrasi dengan penanaman nilai karakter toleransi (Pitaloka, Dimyati, \& Purwanta, 2021). Penanaman nilai karakter toleransi dalam dunia pendidikan bukan hanya menjadi salah satu bentu wujud partisipasi lembaga pendidikan dalam melaksanakan Gerakan Indonesia Bersatu serta implementasi penanaman nilai karakter toleransi dalam dunia pendidikan diharapkan mampu menjadi salah satu upaya bagi generasi penerus bangsa dalam menjaga keutuhan bangsa Indonesia serta mampu mewujudkan masyarakat Indonesia yang sesuai dengan semboyan bangsa kita yakni "Bhinneka Tunggal Ika". Pada artikelnya yang berjudul "SEJARAH DAN KONSEP PENDIDIKAN IPS" yang ditulis oleh Endayani menjelaskan bahwa pendidikan IPS merupakan salah satu mata pelajaran yang diajarkan pada tingkat Sekolah Dasar (SD), Sekolah Menengah Pertama (SMP), dan Sekolah Menengah Atas (SMA) (Endayani, 2018), mata pelajaran ini merupakan suatu displin ilmu yang mencakup seluruh displin ilmu-ilmu sosial. Pada Permendiknas Nomor 22 Tahun 2006 tentang Standar Isi Mata Pelajaran menjelaskan bahwa salah satu tujuan mata pelajaran IPS bertujuan agar peserta didik memiliki kemampuan dalam memiliki kemampan untuk berkomunikasi, bekerjasama, dan berkompetisi dalam masyarakat yang majemuk di tingkat lokal, nasional, dan global. Melalui tujuan dalam Permendiknas Nomor 22 Tahun 2006 tersebut kita dapat mengetahui bahwa lembaga pendidikan khususnya mata pelajaran IPS dapat menjadi wadah atau saran guna mewujudkan terciptanya generasi penerus bangsa atau peserta didik yang mampu hidup berdampingan dan menerima segala kemajemukan yang ada.

Implementasi Gerakan Indonesia Bersatu dalam proses pembelajaran tentu saja melibatkan berbagai unsur dalam suatu proses pembelajaran, baik tujuan pembelajaran, media pembelajaran, teknik, materi dan model pembelajaran. Dalam hal ini diharapkan tujuan, media, teknik, model dan materi pembelajaran dapat mencerminkan unsur-unsur penanaman nilai toleransi. Pendidik dan peserta didik juga menjadi unsur penting dalam proses pembelajaran, pendidik menjadi salah satu unsur yang memiliki peran dalam menanamkan nilai toleransi kepada peserta didik, dalam Undang-Undang RI Nomor 14 Tahun 2005 pada Bab 2 Pasal 4 Tentang Guru dan Dosen menjelaskan bahwa guru memiliki tugas sebagai pendidik, pelajar, guru sebagai pembimbing, pengarah, pelatih, dan menjadi penentu dalam mencapai suatu tujuan 
pembelajaran peserta didik. Melalui UndangUndang RI Nomor 14 Tahun 2005 terlihat jelas bahwa pendidik memiliki peran yang sangat penting dalam menanamkan nilai toleransi dan mengintergrasikan setiap unsur dalam proses pembelajaran dengan upaya untuk menanamkan nilai toleransi kepada peserta didik.

\section{METODE}

Metode penelitian yang digunakan pada penelitian ini yakni metode deskriptif analisis, pemakaian metode ini dipergunakan agar mampu menguasai serta memberikan cerminan yang jelas menimpa masalah yang terpaut menggunakan isi penelitian ini. Analisis digunakan agar penulis mampu menyusun penelitian ini pada wujud yang sistematis sehingga mengena pada inti perkara serta menerima hasil penelitian yang benar. Penelitian deskriptif merupakan penelitian yang dimaksudkan guna merumuskan data mengenai status sesuatu tanda yang ada, yakni keadaan gejala menurut apa adanya pada disaat penelitian dicoba.

Pada penelitian ini peneliti akan berfokus pada bagaimana cara mewujudkan masyarakat pluralistik yang mampu memahami dan mampu mengimplementasikan konsep masyarakat majemuk dan rasa toleransi satu sama lain, sebagai bentuk wujud Gerakan Indonesia Bersatu melalui proses pembelajaran.

\section{PEMBAHASAN}

Gerakan Indonesia Bersatu adalah gerakan para penyelenggara negara dan masyarakat untuk mewujudkan perilaku saling menghargai dan gotong royong untuk memperkuat jati diri dan karakter bangsa berdasarkan Pancasila, UUD 1945, Bhineka Tunggal Ika, dan NKRI. Fokus program Gerakan Indonesia Bersatu terdiri dari:

1. Peningkatan perilaku yang mendukung kehidupan demokrasi Pancasila.

2. Peningkatan perilaku toleran dan kerukunan inter dan antarumat beragama.

3. Peningkatan perilaku yang mendukung kesadaran nasionalisme, patriotisme dan kesetiakawanan sosial.
4. Peningkatan kebijakan yang mendukung persatuan dan kesatuan bangsa.

5. Peningkatan perilaku yang memberikan pengakuan dan perlindungan terhadap kaum minoritas, marjinal dan berkebutuhan khusus

6. Peningkatan dukungan terhadap inisiatif dan peran masyarakat dalam pembangunan.

7. Peningkatan perilaku kerjasama inter dan antarlembaga, komponen masyarakat, dan lantas sektor.

8. Peningkatan penegakan hukum terhadap pelaku pelanggaran yang mengganggu persatuan dan kesatuan bangsa.

9. Penyelenggaraan penidikan agama yang mengajarkan keragaman, toleransi, dan budi pekerti.

10. Peningkatan peran lembaga agama, keluarga, dan media publik dalam persemaian nilai-nilai budi pekerti, toleransi, dan hidup rukun.

Gerakan Indonesia Bersatu memiliki fokus yakni mewujudkan insan manusia yang bisa saling menghargai artinya memiliki rasa dan sikap toleransi yang tinggi di dalam kehidupan bermasyarakat, berbangsa dan bernegara, untuk itu diperlukan adanya penguatan dalam dunia pendidikan yang memfokuskan pemahaman dan pengimplementasian mengenai kehidupan bertoleransi dan saling menghargai dengan pendidikan karakter maupun pendidikan kewarganegaraan. Sebelum kita masuk ke dalam implementasi atau peran pendidikan dalam mewujudkan insan manusia yang bertoleransi, kita harus memahami dahulu pengertian toleransi.

Toleransi merupakan salah satu bentuk akomodasi tanpa persetujuan yang formil, seringkali toleransi timbul secara tidak sadar dan tanpa direncanakan, hal mana disebabkan karena adanya watak orang perorangan atau kelompok manusia, untuk sedapat mungkin menghindarkan diri dari suatu perselisihan (Soekanto, 1982). Toleransi dalam bahasa Latin, yaitu "tolerantia", yang memiliki arti kelonggaran, kelembutan hati, keringanan dan kesabaran. Secara umum istilah toleransi 
mengacu pada sikap saling terbuka, permisif, tulus dan lembut.

Berdasarkan pengertian-pengertian diatas dapat dipahami bahwa toleransi merupakan suatu sikap saling menghormati dan menerima dengan rendah hati terhadap perbedanperbedaan atau keberagaman yang ada. Manusia yang memiliki sikap toleransi ialah manusia yang sabar, lapang dada, menghargai, dan menerima karena tanpa sikap tersebut akan akan sulit bahwa toleransi tertanam dalam kehidupan masyarakat yang beragam. Sikap toleransi dalam kehidupan masyarakat tidak bisa timbul dari sebelah pihak namun harus melibatkan seluruh anggota masyarakat yang besar. Sikap toleransi ini hendaknya dimiliki oleh setiap individu, dengan adanya sikap toleransi suatu komunitas atau masyarakat dapat hidup berdampingan secara damai, rukun, dan bekerja sama dalam mengatasi berbagai permasalahan yang terjadi dilingkungannya.

Sikap toleransi ini bersifat tidak alamiah, dalam arti lain suatu karakter toleransi yang dimiliki oleh seorang indivindu merupakan suatu karakter yang ditanamkan melalui bantuan indivindu lain, salah satunya melalui lembaga pendidikan. Tanpa campur tangan pendidikan, nilai toleransi ini akan sulit untuk dihayati dan dilaksanakan oleh setiap individu. Pendidikan berperan penting dalam mewujudkan dan menciptakan insan insan yang berpendidikan dan juga berkarakter baik, maka dari itu, dunia pendidikan juga berperan penting dalam rangka mewujudkan Gerakan Indonesia Bersatu.

Pendidikan mempunyai fungsi untuk membentuk karakter peserta didik agar sesuai dengan nilai-nilai budaya yang berlaku dalam kehidupan sosial. Pendidikan toleransi sangat penting untuk diajarkan dan diterapkan sejak dini karena sesuatu yang dimulai sejak dini itu akan lebih mudah untuk diterapkan dan dilaksanakan dalam jangka waktu yang panjang. Guru memiliki peran penting dalam bidang pendidikan. Berdasarkan Undang-Undang RI Nomor 14 Tahun 2005 Bab 2 Pasal 4 Tentang Guru dan Dosen, seorang guru memiliki tugas, antara lain: guru sebagai pendidik, guru adalah seorang pendidik yang menjadi tokoh dan panutan bagi peserta didik dan lingkungannya; guru sebagai pelajar, guru bertugas untuk membantu peserta didik dalam meneruskan dan mengembangkan ilmu dan teknologi.

Dalam lembaga pendidikan, guru berperan sangat penting dalam proses mengarahkan dan menerapkan karakter-karakter yang mulia termasuk pula nilai-nilai toleransi kepada peserta didik, didalam dunia pendidikan sosok guru menjadi contoh dan panutan bagi muridmuridnya. Guru memiliki peran yang sangat penting dalam menanamkan nilai toleransi dengan mengintegrasikan pendidikan dengan berbagai nilai-nilai karakter. Perilaku seorang guru di kelas menjadi kunci dalam membantu semua siswanya mencapai potensi tanpa memandang jenis kelamin, etnis, usia, agama, bahasa atau keistimewaan (Pitaloka, Dimyati, \& Purwanta, 2021). Untuk itu, sebagai seorang guru hendaknya guru bisa mencerminkan nilai toleransi dan melibatkan serta menerapkan unsur-unsur nilai toleransi dalam setiap proses pembelajarannya.

Tetapi bukan hanya guru saja yang menjadi satu-satunya pemeran penting dalam hal menerapkan nilai toleransi, keterlibatan unsurunsur pembelajaran lainnya seperti media pembelajaran, model pembelajaran, dan unsurunsur lainnya juga sangat diperlukan. Pada proses pembelajaran IPS, konten materi yang disajikan merupakan permasalahanpermasalahan atau topik-topik yang berkaitan erat dengan kehidupan sosial masyarakat, khususnya permasalahan mengenai toleransi dan keberagaman masyarakat Indonesia. Pada Kompetensi Dasar 3.2 Kelas VIII mata pelajaran IPS, konten materi yang tercantum pada kompetensi dasar tersebut yakni mengenai Pluralitas (agama, budaya, suku bangsa, pekerjaan masyarakat Indonesia). Konten materi tersebut dapat menjadi salah satu bentuk implementasi Gerakan Indonesia Bersatu sebagai bentuk wujud Gerakan Nasional Revolusi Mental dalam pendidikan. Dalam hal ini juga materi tersebut dalam mata pelajaran IPS, dapat menjadi salah satu upaya dalam mencapai tujuan Gerakan Indonesia Bersatu. 
Unsur-unsur lainnya seperti media pembelajaran dan model pembelajaran juga sangat diperlukan dalam menyajikan materi pluralitas tersebut, sehingga tujuan materi tersebut dan khususnya tujuan Gerakan Indonesia Bersatu dapat tercapai. Penggunaan media pembelajaran juga memiliki peranan penting dalam menyajikan suatu konten materi, dalam hal ini media pembelajaran memiliki peranan guna mempermudah komunikasi antar peserta didik dan pendidik serta mempermudah peserta didik dalam memahami materi yang disampaikan. Selain media pembelajaran, unsur lainnya yang juga memiliki peranan yang sangat penting dalam mencapai suatu tujuan pembelajaran yakni model pembelajaran atau strategi pembelajaran. Pada bukunya yang berjudul "STRATEGI PEMBELAJARAN BERORIENTASI STANDAR PROSES PENDIDIKAN" yang ditulis oleh Sanjaya, menjelaskan bahwa strategi pembelajaran merupakan rencana tindakan (rangkaian kegiatan) termasuk penggunaan metode dan pemanfaatan berbagai sumber daya/kekuatan dalam pembelajaran (Sanjaya, 2006). Penggunaan media pembelajaran dan model pembelajaran merupakan kebebasan guru sehingga tujuan pembelajaran dapat tercapai, dalam hal ini pendidik harus cermat dalam menentukan penggunaan media pembelajaran serta menentukan strategi pembelajaran yang akan digunakan dalam mencapai tujuan pembelajaran tersebut.

\section{SIMPULAN}

Berdasarkan pembahasan hasil artikel yang telah dipaparkan sebelumnya, Gerakan Indonesia Bersatu merupakan para penyelenggara negara dan masyarakat untuk mewujudkan perilaku saling menghargai dan gotong royong untuk memperkuat jati diri dan karakter bangsa. Dalam rangka mewujudkan gerakan Indonesia bersatu yang mana fokus daripada gerakan ini adalah untuk mewujudkan insan manusia yang bisa saling menghargai artinya memiliki rasa dan sikap toleransi yang tinggi di dalam kehidupan bermasyarakat, berbangsa dan bernegara.
Toleransi adalah suatu sikap saling menghormati dan menerima dengan rendah hati terhadap, perbedan-perbedaan yang terjadi. Manusia yang memiliki sikap toleransi ialah manusia yang sabar, lapang dada, menghargai, dan menerima karena tanpa sikap tersebut akan akan sulit bahwa toleransi akan tertanam dalam kehidupan masyarakat yang beragam.

Gerakan Indonesia Bersatu sebagai salah satu bentuk wujud Gerakan Nasional Revolusi Mental menjadi salah satu upaya pemerintah Indonesia dalam mewujudkan masyarakat plural yang memahami dan menghormati adanya keberagaman dalam kehidupan sosial masyarakat Indonesia. Lembaga pendidikan juga memiliki peranan dalam mewujudkan dan mengimplementasikan Gerakan Indonesia Bersatu khususnya dalam mewujudkan generasi bangsa sebagai bagian masyarakat plural Indonesia.

Pendidikan IPS menjadi salah satu upaya atau wadah dalam melaksanakan proses Implementasi Gerakan Indonesia Bersatu sebagai bentuk wujud Gerakan Nasional Revolusi Mental dalam lingkup lembaga pendidikan. Pendidikan IPS merupakan suatu displin ilmu yang terdiri dari berbagai displin ilmu-ilmu sosial dan merupakan mata pelajaran yang diajarkan pada tingkat SD hingga SMA. Pendidikan IPS memiliki tujuan yakni menciptakan peserta didik menjadi masyarakat yang demokratis dan mampu menjadi masyarakat yang memiliki kemampuan dalam hidup ditengah kemajemukan.

Konten materi yang disajikan dalam proses pembelajaran IPS merupakan topik-topik yang berkaitan dengan kehidupan sosial masyarakat, tentu saja hal ini mencerminkan tujuan Pendidikan IPS guna menciptakan generasi bangsa yang mampu menggunakan pengetahuan serta keterampilannya dalam menyelesaikan suatu permasalahan dalam kehidupan sosial dan mampu menjadi masyarakat yang baik. Konflik yang dilatarbelakangi karena keberagaman masyarakat Indonesia menjadi salah satu permasalahan yang masih harus terus dihadapi oleh masyarakat Indonesia, Gerakan Indonesia 
Bersatu menjadi salah satu upaya pemerintah dalam mencegah serta menyelesaikan permasalahan tersebut serta berusaha membentuk karakter toleransi masyarakat Indonesia. Materi pluralitas dalam mata pelajaran IPS pada tingkat Sekolah Menengah Pertama (SMP) menjadi salah satu dalam materi yang dapat memfasilitasi implementasi Gerakan Indonesia Bersatu dalam pendidikan khususnya dalam proses pembelajaran IPS. Keterlibatan atau kolaborasi unsur-unsur pada proses pembelajaran seperti tujuan pembelajaran, media pembelajaran, strategi pembelajaran, pendidik serta unsur-unsur lainnya juga menjadi faktor penting dalam proses implementasi Gerakan Indonesia Bersatu pada proses pembelajaran IPS

\section{DAFTAR PUSTAKA}

Bakar, A. (2015). KONSEP TOLERANSI DAN KEBEBASAN BERAGAMA. TOLERANSI: Media Komunikasi Umat Beragama, 123-131.

Endayani, H. (2018). SEJARAH DAN KONSEP PENDIDIKAN IPS. ITTIHAD, 117-127.

Nawir, D., \& Zultan, A. (2018). PEMBERDAYAAN MASYARAKAT WILAYAH 3T (TERDEPAN, TERLUAR, TERTINGGAL) DI KECAMATAN SEBATIK BARAT KABUPATEN NUNUKAN MELALUI REVOLUSI MENTAL DALAM MEWUJUDKAN INDONESIA BERSIH DAN INDONESIA BERSATU. JURNAL PENGABDIAN MASYARAKAT BORNEO, 44-50.

Pitaloka, D. L., Dimyati, \& Purwanta, E. (2021). Peran Guru dalam Menanamkan Nilai Toleransi pada Anak Usia Dini di Indonesia. Jurnal Obsesi : Jurnal Pendidikan Anak Usia Dini, 1696-1705.

Samani, M., \& Hariyanto. ( 2020). Konsep dan Model Pendidikan Karakter. Bandung: PT REMAJA ROSDAKARYA.

Sanjaya, W. (2006). STRATEGI PEMBELAJARAN BERORIENTASI STANDAR PROSES PENDIDIKAN. Jakarta: KENCANA PRENADA MEDIA.

SODIK, F. (2020). PENDIDIKAN TOLERANSI DAN RELEVANSINYA DENGAN
DINAMIKA SOSIAL MASYARAKAT INDONESIA. Tsamratul Fikri, 1-14.

Soekanto, S. (1982). Sosiologi Suatu Pengantar. Jakarta: Rajawali. 